\title{
Salicylic Acid Is Important for Basal Defense of Solanum tuberosum Against Phytophthora infestans
}

\author{
Vincentius A. Halim, Lennart Eschen-Lippold, Simone Altmann, Mandy Birschwilks, Dierk Scheel, and \\ Sabine Rosahl
}

Leibniz Institute of Plant Biochemistry, Department of Stress and Developmental Biology, Weinberg 3, D-06120 Halle

(Saale), Germany

Submitted 16 March 2007. Accepted 9 July 2007.

\begin{abstract}
The importance of the signaling compound salicylic acid for basal defense of potato (Solanum tuberosum L. cv. Désirée) against Phytophthora infestans, the causal agent of late blight disease, was assessed using transgenic NahG potato plants which are unable to accumulate salicylic acid. Although the size of lesions caused by $P$. infestans was not significantly different in wild-type and transgenic $N a h G$ plants, real-time polymerase chain reaction analyses revealed a drastic enhancement of pathogen growth in potato plants depleted of salicylic acid. Increased susceptibility of $N a h G$ plants correlated with compromised callose formation and reduced early defense gene expression. NahG plants pretreated with the salicylic acid analog 2,6dichloro-isonicotinic acid allowed pathogen growth to a similar extent as did wild-type plants, indicating that salicylic acid is an important compound required for basal defense of potato against $P$. infestans.
\end{abstract}

Salicylic acid (SA), jasmonic acid (JA), and ethylene activate and mediate defense responses against pathogens in a number of plant species (Shah 2003). In Arabidopsis thaliana, $\mathrm{SA}$ is important for both basal defense and resistance $(R)$ gene-mediated resistance, as well as for either the establishment or maintenance, or both, of systemic acquired resistance (SAR) (Durrant and Dong 2004). SA accumulation induced in response to pathogen infection requires de novo biosynthesis via the isochorismate pathway in Arabidopsis (Wildermuth et al. 2001), which is controlled by EDS1 and PAD4, proteins with homology to lipases (Wiermer et al. 2005; Zhou et al. 1998). Although the mechanisms of SA perception are still unclear, the components of the SA signal transduction chain consist of an oxidative burst (Overmyer et al. 2003), activation of MAP kinase cascades (Zhang and Klessig 1997), and the induction of defense gene expression (Ward et al. 1991). As a central regulator required for SA signaling, the ankyrin-repeatcontaining protein NPR1 (nonexpressor of PR1) was identified in mutant screens of Arabidopsis (Cao et al. 1994; Delaney et al. 1995; Shah et al. 1997). NPR1, present in the cytoplasm presumably as an oligomer, translocates to the nucleus in its monomeric form upon pathogen-induced alterations in the cellular redox state (Dong 2004; Fobert and Despres 2005). Activation of defense gene expression is mediated by interaction of

Corresponding author: Sabine Rosahl: E-mail: srosahl@ipb-halle.de

Current address of V. A. Halim: Max Planck Institute for Chemical Ecology, Research Group Mass Spectrometry, Hans-Knöll-Straße 8, D-07745 Jena, Germany.
NPR1 with distinct TGA transcription factors in the nucleus (Despres et al. 2000; Niggeweg et al. 2000; Zhou et al. 2000). Moreover, the NPR1-interacting proteins NIMIN1 and NIMIN2 modulate SA-induced NPR1-mediated responses (Weigel et al. 2005).

Based on studies in Arabidopsis, it appears that, in a number of cases, the life style of a pathogen determines which signal transduction pathway becomes activated, with biotrophic pathogens inducing defense responses via the SA signaling pathway (McDowell and Dangl 2000). JA-dependent defense responses, on the other hand, are considered to be activated in Arabidopsis in response to infection with necrotrophic pathogens which require host cell death to obtain nutrients (Glazebrook 2005).

The oomycete Phytophthora infestans is a hemibiotrophic pathogen which causes late blight disease of potato. Susceptible potato plants are infected by penetration of the epidermal cells or by direct entry of the pathogen into the leaf tissue via the stomata. The biotrophic phase is characterized by formation of haustoria-like feeding structures inside penetrated cells, whereas intercellular growth of the pathogen as well as active killing of plant cells during the necrotrophic phase result in the rapid destruction of the tissue as well as the whole plant. Basal defense responses are activated in susceptible plants; however, they are not sufficient to arrest pathogen growth. Enhanced resistance can be induced in susceptible plants by pre-inoculation with the heterologous pathogen Pseudomonas syringae (Kombrink et al. 1996, 1997) or by treatment with elicitors such as arachidonic acid (Coquoz et al. 1995).

Compared with tobacco and Arabidopsis, SA is present at elevated levels in uninfected potato plants (Yu et al. 1997). Interestingly, its role in pathogen defense in potato appears to be different from that in Arabidopsis and tobacco. First, application of exogenous SA does not lead to SAR (Coquoz et al. 1995). Second, induction of SAR by arachidonic acid (Coquoz et al. 1995) or infiltration of Pseudomonas spp. (P. Landgraf, D. Scheel, and S. Rosahl, unpublished) does not lead to systemic accumulation of SA. Third, disease lesion size is unaltered in transgenic potato plants unable to accumulate SA due to the expression of the NahG gene encoding a salicylate hydroxylase, suggesting that the signaling compound SA does not play a role in defense against Phytophthora infestans (Yu et al. 1997).

In order to elucidate the role of SA for defense responses in potato, we analyzed transgenic potato plants expressing the $N a h G$ gene for alterations in their response to infection with $P$. infestans. In susceptible potato plants with reduced levels of $\mathrm{SA}, P$. infestans can grow to higher extents than in control plants, suggesting that SA is important for basal defense in potato. 


\section{RESULTS}

Impaired SA accumulation in $N a h G$ potato plants in response to infection by $P$. infestans.

We previously have reported the generation of potato (Solanum tuberosum cv. Désirée) plants expressing the $N a h G$ gene encoding a salicylate hydroxylase (Halim et al. 2004). To analyze whether SA accumulation is efficiently reduced after pathogen infection, the levels of SA and its glucoside, salicylic acid glucoside (SAG), were determined in the wild type and the two $N a h G$ lines (NahG A and $N a h G$ D) after infection with $P$. infestans (Fig. 1). SA and SAG were present in untreated wild-type plants at approximately 0.1 and $1 \mu \mathrm{g} / \mathrm{g}$ fresh weight, respectively (data not shown). Upon infection with $P$. infestans, both compounds increased in wild-type plants approximately twofold, whereas plants expressing the salicylate hydroxylase gene were unable to accumulate SA (Fig. 1A) or SAG (Fig. 1B) to detectable levels.

\section{Increased pathogen biomass in $N a h G$ potato plants.}

Upon infection of susceptible potato cultivars with $P$. infestans, the oomycete generally enters the leaf tissue via stomata or by direct penetration of epidermal cells. Intercellular growth and the formation of feeding structures are followed by host defense responses such as cell death, formation of callose, and accumulation of autofluorescent material (Vleeshouwers et al. 2000). Lesion development usually is observed 2 to 3 days after infection. Interestingly, it was reported that SA is not important in potato for defense against $P$. infestans, based on measurements of lesion size which indicated that disease severity was not increased in transgenic potato $N a h G$ plants (Yu et al. 1997). Indeed, our determinations of the size of $P$. infestans-induced lesions in Désirée and Désirée NahG plants did not reveal significant differences 3 days after infection (Fig. 2A and B). However, microscopic examinations of infected leaves after staining with trypan blue revealed increased
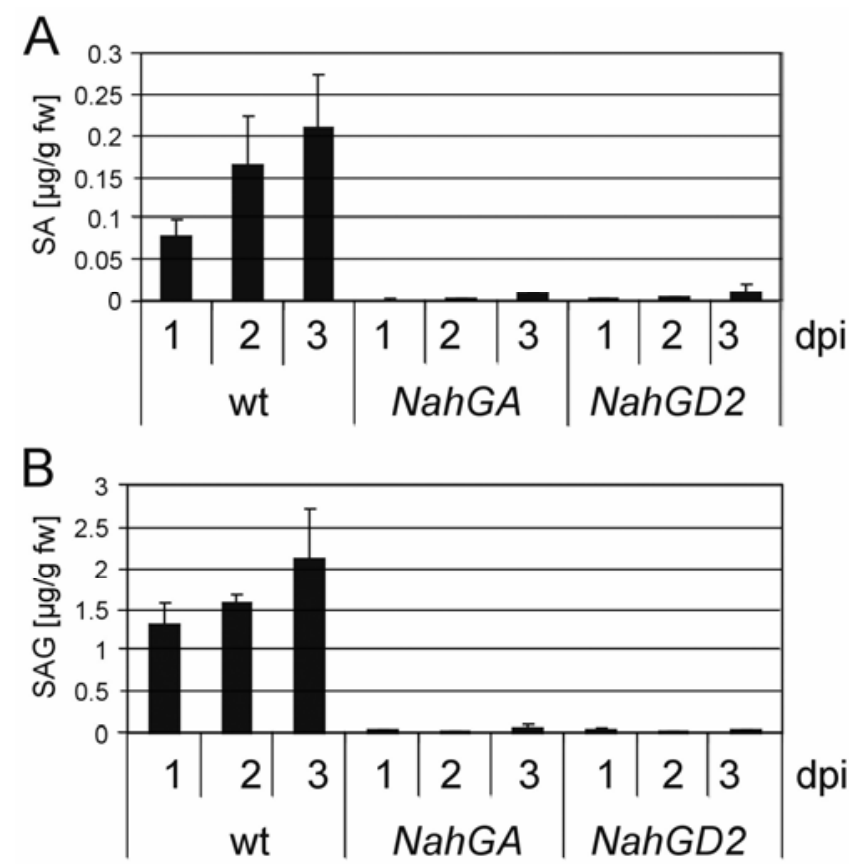

Fig. 1. Accumulation of A, salicylic acid (SA) and B, salicylic acid glucoside (SAG) in potato leaves after infection with Phytophthora infestans. SA and SAG levels were determined in leaves of wild-type (wt) and $N a h G$ potato plants (lines $A$ and $D 2$ ) after infection with $P$. infestans at the time points indicated ( $\mathrm{dpi}=$ days after infection). Error bars represent standard deviation. mycelial growth in $N a h G$ compared with wild-type plants (Fig. 3A). In particular, in wild-type plants, infection sites were characterized by a large number of dead cells, with few incidences of emanating hyphal-like structures. In contrast, a higher number of sites with escaping hyphal-like structures were observed in $N a h G$ plants, suggesting that plants unable to accumulate SA cannot contain pathogen growth to the same extent as wild-type plants. Consequently, $P$. infestans biomass determinations were carried out. Using primers derived from highly repetitive sequences from the $P$. infestans genome (Judelson and Tooley 2000), real-time polymerase chain reaction (PCR) with TaqMan probes was performed and revealed significantly higher pathogen biomass in infected leaves of $N a h G$ plants compared to wild type plants (Fig. 3B). Thus, despite the lack of differences in disease symptoms, growth of $P$. infestans on $N a h G$ potato plants was enhanced, leading to a 10 -fold difference in pathogen biomass 3 days after infection.

\section{Increased pathogen growth on NahG plants correlates} with reduced callose formation.

To study differences in oomycete growth during the early stages of infection of wild-type and NahG plants, microscopic analyses were carried out. In response to pathogen infection, plant cells deposit callose at the penetration sites. Staining of callose with aniline blue revealed striking differences between wild-type plants and those unable to accumulate SA (Fig. 4). Thus, whereas whole cells were stained for aniline blue in the wild type (Fig. 4A), only minor callose depositions could be found in NahG plants (Fig. 4B). These observations indicate that callose deposition is dependent on SA accumulation and that the lack of callose deposition is correlated with increased growth of the oomycete in potato plants.

Moreover, electron microscopic studies demonstrated massive depositions of callose around the sites of oomycete growth in wild-type plants (Fig. 4C) whereas, in NahG plants, $P$. infestans structures were observed close to parenchyma cells that did not react with callose deposition at all, or that reacted to a lesser extent compared with wild-type cells (Fig. 4D).

\section{Increased pathogen growth on $N a h G$ plants correlates with reduced early defense gene expression.}

The electron microscopic analyses suggested that $P$. infestans could spread further in $N a h G$ compared with wild-type plants, possibly due to a reduced response of attacked cells. To substantiate this observation, $P R$ gene expression was analyzed at different time points after infection by Northern analyses (Fig. 5). Indeed, whereas wild-type and empty-vector-transformed plants showed induction of $P R 1$ gene expression 1 day after infection, NahG plants did so only after 2 days. Differences in PRI transcript levels were not visible 3 days after infection. Thus, the reduction of SA levels in NahG potato plants correlated with decreased early defense responses and higher pathogen growth.

\section{Pretreatment of $\mathrm{NahG}$ plants \\ with 2,6-dichloroisonicotinic acid restores wild-type growth of $P$. infestans.}

2,6-Dichloroisonicotinic acid (INA) induces a spectrum of defense responses similar to that of SA and is considered to be an analog of SA. To address the question of whether enhanced susceptibility of $N a h G$ potato plants against $P$. infestans is based on the inability to accumulate $\mathrm{SA}$, a solution of $0.3 \mathrm{mM}$ INA was sprayed onto leaves of NahG and control plants $24 \mathrm{~h}$ before infection with $P$. infestans. Pathogen biomass at 3 days after infection was determined by real-time PCR (Fig. 6). Pretreatment of $N a h G$ potato plants with INA resulted in pathogen growth similar to that observed on wild-type plants. Thus, 
A

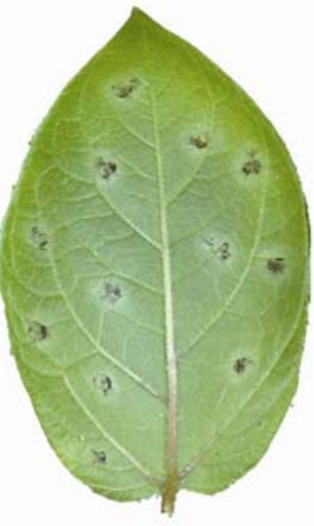

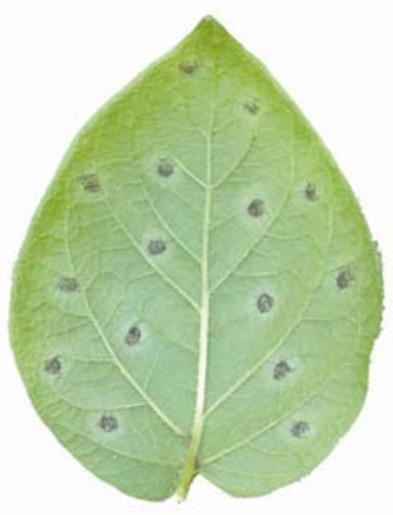

NahGA

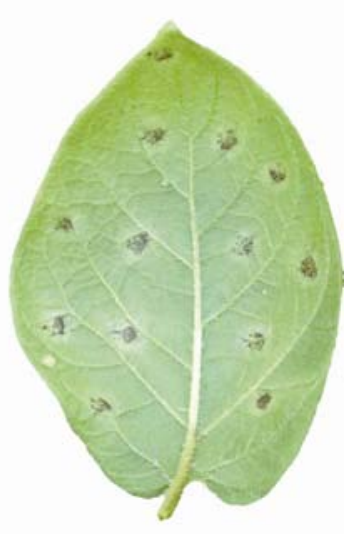

NahGD2

B

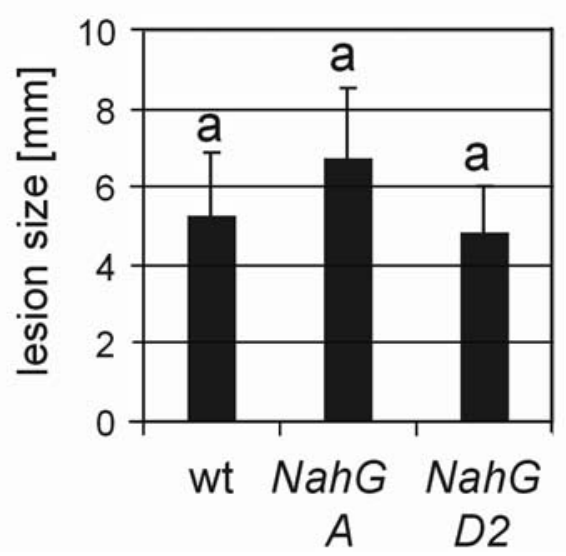

Fig. 2. A, Phenotype and B, diameter of disease lesions 3 days after infection of wild-type (wt) and transgenic $N a h G$ plants (lines $A$ and $D 2$ ) with $P h y t o p h$ thora infestans. Error bars represent standard deviation. Same letters indicate non-significant difference using one-way analysis of variance with Tukey's post hoc test $(P=0.01, n=10$, two independent experiments).

A

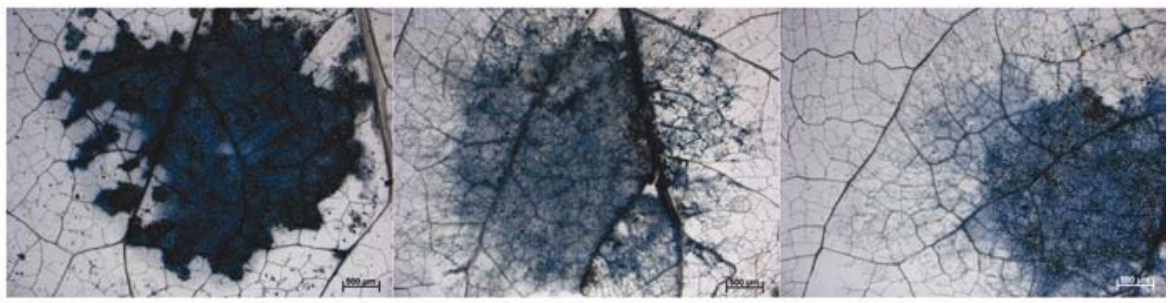

wt

NahGA

NahGD2

B

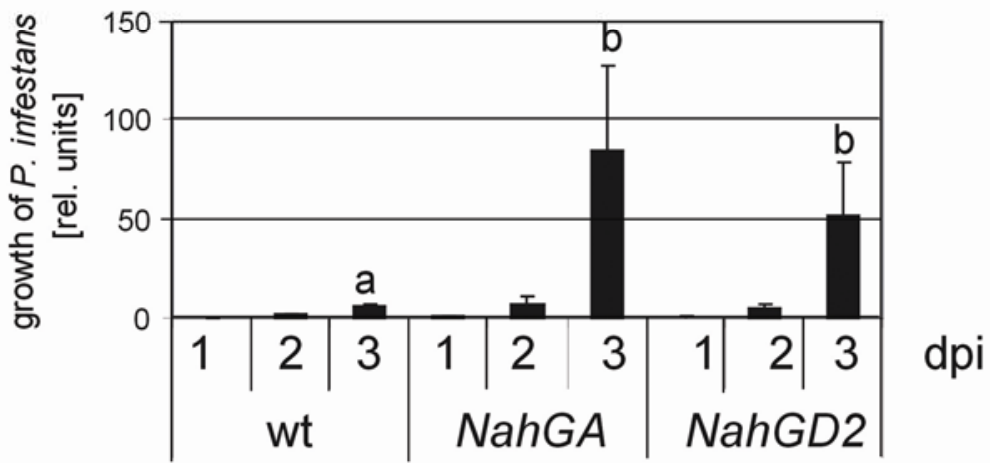

Fig. 3. Growth of Phytophthora infestans on wild-type (wt) and NahG potato plants. A, Microscopic analysis of disease lesions and oomycete structures, visualized by trypan blue staining in wt and $N a h G$ potato plants 3 days after infection with $P$. infestans (bars represent $500 \mu m$ ). B, Determination of pathogen biomass by real-time polymerase chain reaction $(\mathrm{PCR})$ after infection of wt and $N a h G$ plants at the time points indicated $(\mathrm{dpi}=\mathrm{days}$ post inoculation). Real-time PCR was performed with $P$. infestans-specific primers using DNA isolated from leaf disks of infected plants. Error bars represent standard deviation. Different letters indicate significant difference using one-way analysis of variance with Tukey's Post Hoc Test $(P=0.01, n=12$, two independent experiments). 
these results suggest that reduced basal defense against $P$. infestans in NahG plants is due to the lack of SA because it can be overcome by supplying the SA analog INA.

\section{DISCUSSION}

$N a h G$ plants are unable to accumulate SA due to the expression of a salicylate hydroxylase which catalyzes the conversion of SA to catechol. They have been widely used to demonstrate a role for SA in mediating defense responses in Arabidopsis and tobacco (AbuQamar et al. 2006; Chen et al. 2004; Delaney et al. 1994). In contrast, in potato, expression of the NahG gene was reported to have no effect on infection by $P$. infestans (Yu et al. 1997). These results were based on measuring lesion size which, indeed, is very similar in wild-type and $N a h G$ plants infected with $P$. infestans (Fig. 2). However, using realtime PCR to determine pathogen biomass, we observed a significantly higher growth of $P$. infestans on NahG plants (Fig. 3 ). These results suggest that the inability to accumulate SA might be responsible for enhanced susceptibility. However, phenotypes of NahG plants might result, on the one hand, from the inability to accumulate SA or, on the other hand, from the accumulation of catechol or a product thereof (Heck et al. 2003; van Wees and Glazebrook 2003). To address the question of whether catechol could enhance susceptibility to $P$. infestans, wild-type plants were sprayed with $1 \mathrm{mM}$ catechol solution $24 \mathrm{~h}$ prior to infection with $P$. infestans. Real-time PCR assays did not show significant differences in pathogen biomass between plants sprayed with water or with catechol (data not shown), suggesting that catechol itself does not induce susceptibility to $P$. infestans. Moreover, it was possible to restore the low level of pathogen growth observed on wild-type plants when $N a h G$ plants were sprayed with INA. As an SA analog, INA is able to overcome the loss of SA accumulation and to activate SA-dependent responses (Uknes et al. 1992).

Activation of the SA and JA defense signaling pathways in Arabidopsis has been proposed to be dependent on the life style of the pathogen (McDowell and Dangl 2000). In response
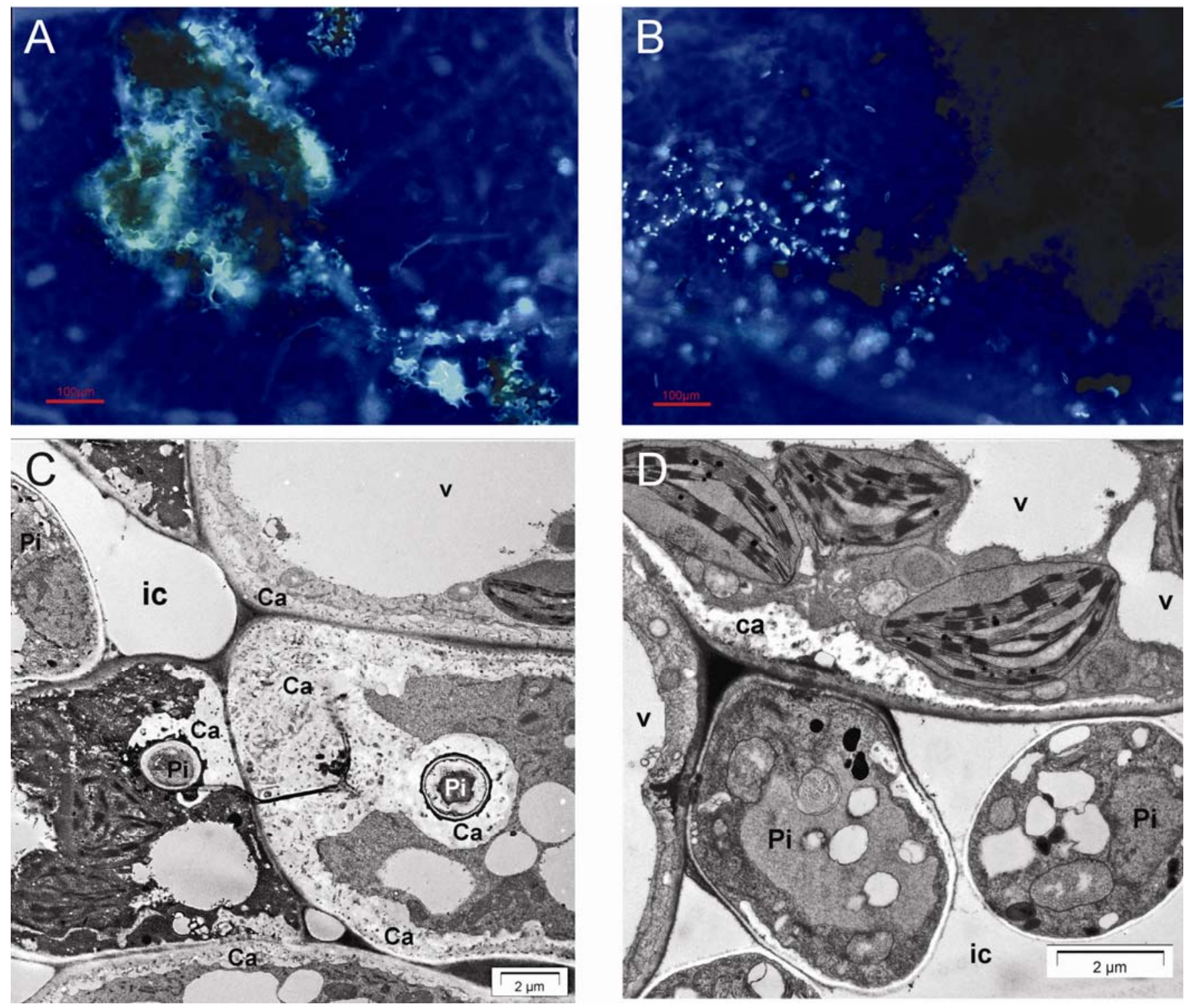

Fig. 4. Microscopic analyses of $\mathbf{A}$ and $\mathbf{C}$, wild-type (wt) and $\mathbf{B}$ and $\mathbf{D}, N a h G$ plants after infection with Phytophthora infestans. A and $\mathbf{B}$, Infected leaves were stained with aniline blue for callose depositions (fluorescing areas). Bar represents $100 \mu \mathrm{m}$. $\mathbf{C}$ and $\mathbf{D}$, Electron microscopy of mesophyll cells 3 days after infection with $P$. infestans. Oomycete structures are characterized by unstained cell walls (white in appearance) and their lack of plastids. They are visible both within and between cells due to intra- and intercellular growth at this time point of infection. $\mathrm{Ca}=$ callose, ic $=$ intercellular space, $\mathrm{Pi}=P$. infestans, and $\mathrm{v}=$ vacuole. Bar represents $2 \mu \mathrm{m}$. 
to infection with biotrophic pathogens, which depend on obtaining nutrients from living host cells, plants activate the SA pathway, which leads to expression of $P R$ genes and hypersensitive cell death. On the other hand, JA-dependent defense responses are necessary for successful defense against necrotrophic pathogens such as Alternaria brassicicola or Botrytis cinerea (Thomma et al. 1998). However, exceptions to this model include, for example, the enhanced susceptibility toward Botrytis spp. of NahG plants (Ferrari et al. 2003) and the enhanced resistance toward biotrophs in Arabidopsis mutants with constitutive activation of the JA signaling pathway (Ellis et al. 2002). Moreover, because many pathogens which are considered to be necrotrophic undergo a biotrophic phase during the initial invasion of the plant, a clear distinction between biotrophic and necrotrophic life style is not always possible (Thaler et al. 2004).

Infection of potato plants with the hemibiotrophic oomycete $P$. infestans generally starts via germination of encysted zoospores on the leaf surface and appressorium formation. The initial phases of infection, comprising penetration of epidermal cells and formation of infection structures, resemble those of biotrophic pathogens. The plant reaction to infection by biotrophic pathogens includes cell wall appositions, callose formation, and activation of defense genes (Latijnhouwers et al. 2003). Our data suggest that, in potato, SA is required for maximal defense responses of potato during this biotrophic phase of $P$. infestans infection, because the inability to accumulate SA results in a loss of callose deposition and defense gene expression at early time points (Figs. 4 and 5). Moreover, hyphal structures emerge from the site of primary infection in $N a h G$ plants, whereas wild-type plants still are able to contain pathogen growth at this point to a higher extent (Fig. 3A). Thus, it appears that SA is important in potato for defense against $P$. infestans during the early phase of infection.

Callose deposition, which generally is considered to be an effective barrier against fungal ingress, is an SA-dependent process (Donofrio and Delaney 2001). In accordance with this,

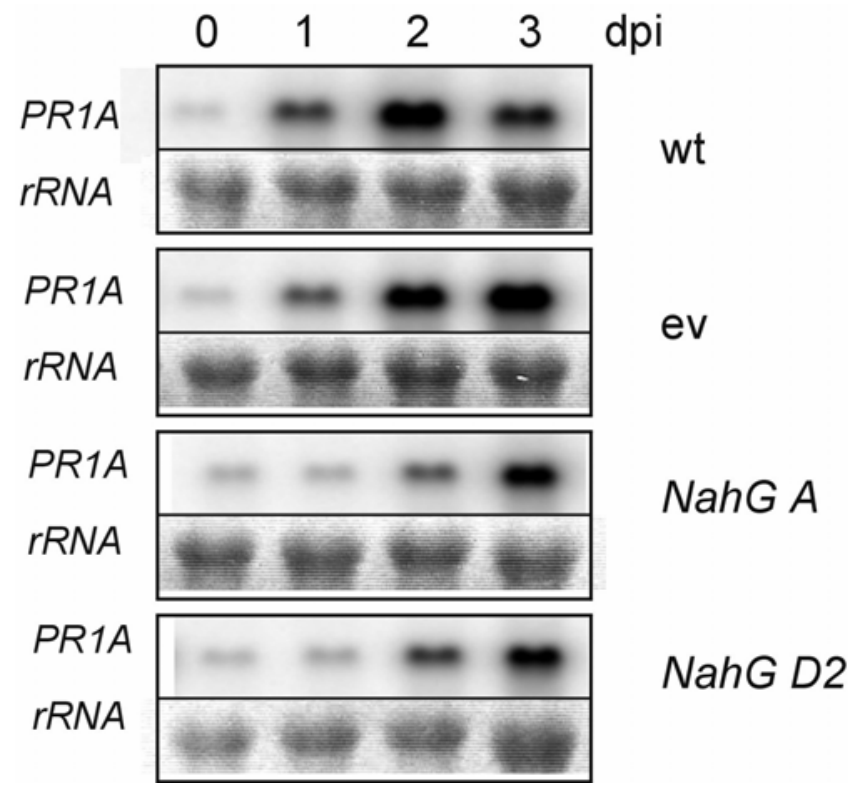

Fig. 5. $P R 1 A$ expression in wild-type (wt) and $N a h G$ plants in response to infection with Phytophthora infestans. RNA was isolated from leaves of wt and transgenic plants carrying an empty vector construct (ev) or the $N a h G$ gene (NahGA and NahGD2) and subjected to Northern analyses. Hybridization was carried out with a radioactively labeled cDNA fragment of StPR1A. As a loading control, the agarose gel was stained with ethidium bromide to visualize rRNA. reduced callose formation is observed in NahG potato plants after infection with $P$. infestans. However, the recent isolation of mutant Arabidopsis lines defective in callose synthase genes or the generation of transgenic plants compromised in callose synthase gene expression revealed that loss of callose deposition actually enhances resistance against Erysiphe cichoracearum and Golovinomyces orontii (Jacobs et al. 2003; Nishimura et al. 2003). Possibly, callose formation by the plant enables virulent pathogens to avoid recognition. Interestingly, SA responses are hyperinduced in the pmr4 mutant, which is defective in the gene encoding the pathogen-induced callose synthase (Nishimura et al. 2003). Pathogen susceptibility can be restored in double mutants impaired in SA accumulation or signaling, indicating that callose might function as a suppressor of SAdependent defense responses (Nishimura et al. 2003). Thus, there is a discrepancy between the absence of callose in $N a h G$ plants (Donofrio and Delaney 2001) (Fig. 4) and enhanced SA responses in callose-deficient plants, suggesting the existence of a complex network of SA-dependent defense signaling, possibly including negative feedback loops (Nishimura et al. 2003).

The necrotrophic phase of infection by $P$. infestans is characterized by disease lesions. The fact that lesion size is not altered in NahG compared with wild-type plants (Fig. 2) suggests that the same number of cells undergo cell death. At this time point, however, more hyphae have escaped from the primary infection site. Interestingly, $P R I$ gene expression is not different at later stages of infection (Fig. 5). These observations suggest that differences in the strength of defense responses are eliminated at later time points due to the infection of more cells in $N a h G$ plants, where the oomycete can spread further. Thus, our data suggest that lack of SA increases susceptibility in compatible interactions of potato with $P$. infestans and that $\mathrm{SA}$ is required in susceptible potato cultivars for defense responses such as $P R$ gene expression and callose deposition at early time points after infection.

\section{MATERIALS AND METHODS}

Treatment of plants and analysis of defense responses.

Sterile potato plants ( $S$. tuberosum L. cv. Désirée) were grown in tissue culture in a phytochamber with $16 \mathrm{~h}$ of light $(140 \mu \mathrm{E})$ at $22^{\circ} \mathrm{C}$. Plants were transferred to soil and grown in a phytochamber with $16 \mathrm{~h}$ of light $(140 \mu \mathrm{E})$ at $20^{\circ} \mathrm{C}$ and $60 \%$ humidity for 4 weeks. For $P$. infestans infections, lower leaves

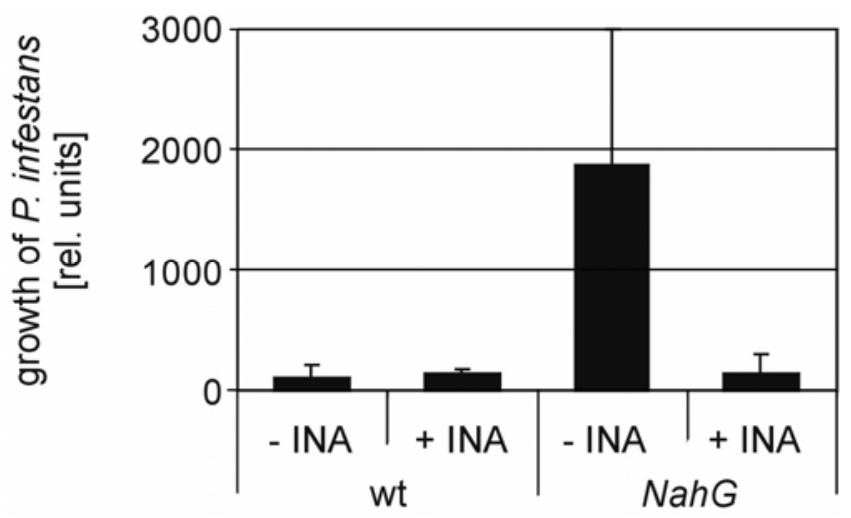

Fig. 6. Pathogen biomass in $N a h G$ plants sprayed with INA. Wild-type (wt) and $N a h G$ plants were treated with $0.3 \mathrm{mM}$ 2,6-dichloroisonicotinic acid (+INA) or mock treated (-INA) 24 h prior to infection with Phytophthora infestans. Pathogen biomass was determined 3 days after infection. Pooled data obtained from two lines of $N a h G$ plants are shown. Error bars represent standard deviation. The experiment was repeated twice with similar results. 
were drop inoculated with a zoospore suspension in water $(1 \times$ $10^{5}$ zoospores $/ \mathrm{ml}$ ) on the abaxial leaf surface and kept at $100 \%$ humidity for the duration of the experiment. As controls, water was pipetted onto the leaves. RNA was isolated from leaves using trizol (Invitrogen, Karlsruhe, Germany) according to the manufacturer's instructions. Northern analyses were carried out as described (Geerts et al. 1994).

To assess the influence of INA and catechol on pathogen growth, 0.3 or $1 \mathrm{mM}$ solutions, respectively, were sprayed onto the adaxial side of detached potato leaves $24 \mathrm{~h}$ before inoculation with $P$. infestans.

\section{Determination of $P$. infestans biomass.}

Quantitative real-time PCR was applied to determine the growth of $P$. infestans on wild-type and transgenic potato plants (Eschen-Lippold et al. 2007). Leaf disks, $6 \mathrm{~mm}$ in diameter, were cut from the inoculation sites. DNA was isolated from six leaf disks using the DNeasy Plant Mini Kit (Qiagen, Hilden, Germany), after addition of external standard DNA. The primers PIO8-3-3F (5'-CAATTCGCCACCTTCTTCGA-3') and PIO83-3R (5'-GCCTTCCTGCCCTCAAGAAC-3') (MWG Biotech, Ebersberg, Germany) as well as the Taqman-MGB-NFQ probe PIO8-3-3M1: 6-FAM-5'-CGTACGGCCAATGTA-3'-MGB-NFQ (Applied Biosystems, Darmstadt, Germany) were used to amplify and detect a $P$. infestans-specific repetitive DNA sequence (Judelson and Tooley 2000) with the ABI Prism Sequence Detection System (Applied Biosystems). For standard curves, a larger DNA fragment was amplified from $P$. infestans genomic DNA with the primers O8-3 (5'-TAACCGACCAAGTAG TAAA-3') and O8-4 (5'-GAAAGGCATAGAAGGTAGA-3') (Judelson and Tooley 2000) and cloned into the vector pCR2.1 (Invitrogen). To detect the external standard plasmid DNA, appropriate primers and a second Taqman-MGB-NFQ probe were designed. PCR was carried out using the Taqman Universal PCR Master Mix (Applied Biosystems, Darmstadt, Germany.) with $10 \mathrm{~min}$ at $95^{\circ} \mathrm{C}$ followed by 40 cycles of $15 \mathrm{~s}$ at $95^{\circ} \mathrm{C}$ and $1 \mathrm{~min}$ at $60^{\circ} \mathrm{C}$ each. Relative amounts of $P$. infestans DNA in the samples was calculated using the ABI Prism 7000 Sequence Detection-Software (version 1.1) by including the external standard and the data from the standard curve. Therefore, pathogen biomass is given as "relative units."

\section{Determination of SA.}

Determination of SA was performed as described (Halim et al. 2004).

\section{Microscopy.}

Trypan blue staining was carried out as described (Lipka et al. 2005). Callose staining was performed with aniline blue according to Adam and Somerville (1996).

\section{Electron microscopy.}

Necrotic regions of the potato leaves were prefixed with $3 \%$

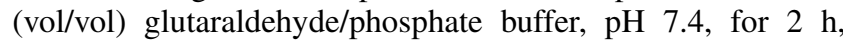
fixed with $1 \%$ (wt/vol) $\mathrm{OsO}_{4} /$ Palade buffer for $1 \mathrm{~h}$, and dehydrated in series of acetone. After being embedded in an epoxide resin, ultrathin sections (50 to $70 \mathrm{~nm}$ ) were stained with lead and viewed using a transmission electron microscope (EM 912 OMEGA LEO Elektronenmikroskopie, Oberkochen, Germany).

\section{ACKNOWLEDGMENTS}

This work was funded by the DFG (SPP1067 "Molecular analysis of phytohormone action," Sche235/10/13) and SFB648 TPA4. The technical assistance of A. Weinel and J. Elster is gratefully acknowledged. R. Dietrich (Syngenta) is gratefully acknowledged for providing the $N a h G$ gene from Pseudomonas putida. We would like to thank L. Westphal for critical reading of the manuscript and I. Widjaja for useful discussions.

\section{LITERATURE CITED}

AbuQamar, S., Chen, X., Dhawan, R., Bluhm, B., Salmeron, J., Lam, S. Dietrich, R. A., and Mengiste, T. 2006. Expression profiling and mutant analysis reveals complex regulatory networks involved in Arabidopsis response to Botrytis infection. Plant J. 48:28-44.

Adam, L., and Somerville, S. C. 1996. Genetic characterization of five powdery mildew disease resistance loci in Arabidopsis thaliana. Plant J. 9:341-356

Cao, H., Bowling, S. A., Gordon, S., and Dong, X. 1994. Characterization of an Arabidopsis mutant that is nonresponsive to inducers of systemic acquired resistance. Plant Cell 6:1583-1592.

Chen, Z., Kloek, A. P., Cuzick, A., Moeder, W., Tang, D., Innes, R. W., Klessig, D. F., McDowell, J. M., and Kunkel, B. N. 2004. The Pseudomonas syringae type III effector AvrRpt2 functions downstream or independently of SA to promote virulence on Arabidopsis thaliana. Plant J. 37:494-504.

Coquoz, J.-L., Buchala, A., Meuwly, P., and Métraux, J.-P. 1995. Arachidonic acid induces local but not systemic synthesis of salicylic acid and confers systemic resistance in potato plants to Phytophthora infestans and Alternaria solani. Phytopathology 85:1219-1224.

Delaney, T., Uknes, S., Vernooij, B., Friedrich, L., Weymann, K., Negrotto, D., Gaffney, T., Gut-Rella, M., Kessmann, H., Ward, E., and Ryals, J. 1994. A central role of salicylic acid in plant disease resistance. Science 266:1247-1250.

Delaney, T. P., Friedrich, L., and Ryals, J. A. 1995. Arabidopsis signal transduction mutant defective in chemically and biologically induced disease resistance. Proc. Natl. Acad. Sci. U.S.A. 92:6602-6606.

Despres, C., DeLong, C., Glaze, S., Liu, E., and Fobert, P. R. 2000. The Arabidopsis NPR1/NIM1 protein enhances the DNA binding activity of a subgroup of the TGA family of bZIP transcription factors. Plant Cell 12:279-290.

Dong, X. 2004. NPR1, all things considered. Curr. Opin. Plant Biol. 7:547-552.

Donofrio, N. M., and Delaney, T. P. 2001. Abnormal callose response phenotype and hypersusceptibility to Peronospora parasitica in defensecompromised Arabidopsis nim1-1 and salicylate hydroxylase-expressing plants. Mol. Plant-Microbe Interact. 14:439-450.

Durrant, W. E., and Dong, X. 2004. Systemic acquired resistance. Annu. Rev. Phytopathol. 42:185-209.

Ellis, C., Karafyllidis, I., and Turner, J. G. 2002. Constitutive activation of jasmonate signaling in an Arabidopsis mutant correlates with enhanced resistance to Erysiphe cichoracearum, Pseudomonas syringae, and Myzus persicae. Mol. Plant-Microbe Interact. 15:1025-1030.

Eschen-Lippold, L., Rothe, G., Stumpe, M., Gobel, C., Feussner, I., and Rosahl, S. 2007. Reduction of divinyl ether-containing polyunsaturated fatty acids in transgenic potato plants. Phytochemistry 68:797-801.

Ferrari, S., Plotnikova, J. M., De Lorenzo, G., and Ausubel, F. M. 2003. Arabidopsis local resistance to Botrytis cinerea involves salicylic acid and camalexin and requires EDS4 and PAD2, but not SID2, EDS5 or PAD4. Plant J. 35:193-205.

Fobert, P. R., and Despres, C. 2005. Redox control of systemic acquired resistance. Curr. Opin. Plant Biol. 8:378-382.

Geerts, A., Feltkamp, D., and Rosahl, S. 1994. Expression of lipoxygenase in wounded tubers of Solanum tuberosum L. Plant Physiol. 105:269-277.

Glazebrook, J. 2005. Contrasting mechanisms of defense against biotrophic and necrotrophic pathogens. Annu. Rev. Phytopathol. 43:205-227.

Halim, V. A., Hunger, A., Macioszek, V., Landgraf, P., Nürnberger, T., Scheel, D., and Rosahl, S. 2004. The oligopeptide elicitor Pep-13 induces salicylic acid-dependent and -independent defense reactions in potato. Physiol. Mol. Plant Pathol. 64:311-318.

Heck, S., Grau, T., Buchala, A., Metraux, J. P., and Nawrath, C. 2003. Genetic evidence that expression of NahG modifies defence pathways independent of salicylic acid biosynthesis in the Arabidopsis-Pseudomonas syringae pv. tomato interaction. Plant J. 36:342-352.

Jacobs, A. K., Lipka, V., Burton, R. A., Panstruga, R., Strizhov, N., Schulze-Lefert, P., and Fincher, G. B. 2003. An Arabidopsis callose synthase, GSL5, is required for wound and papillary callose formation. Plant Cell 15:2503-2513.

Judelson, H. S., and Tooley, P. W. 2000. Enhanced polymerase chain reaction methods for detecting and quantifying Phytophthora infestans in plants. Phytopathology 90:1112-1119.

Kombrink, E., Büchter, R., Wegener, S., and Scheel, D. 1996. Systemic acquired resistance in potato. Pages 483-491 in: Modern Fungicides and Antifungal Compounds. H. Lyr, P. E. Russell, and H. D. Sisler, eds. Intercept, Andover, U.S.A. 
Kombrink, E., Buechter, R., Dietrich, J., Hoegen, E., Wegener, S., and Scheel, D. 1997. Gene activation and signaling during systemic acquired resistance in potato. Plant Physiol. 114:39-39.

Latijnhouwers, M., de Wit, P. J., and Govers, F. 2003. Oomycetes and fungi: Similar weaponry to attack plants. Trends Microbiol. 11:462-469.

Lipka, V., Dittgen, J., Bednarek, P., Bhat, R., Wiermer, M., Stein, M., Landtag, J., Brandt, W., Rosahl, S., Scheel, D., Llorente, F., Molina, A., Parker, J., Somerville, S., and Schulze-Lefert, P. 2005. Pre- and postinvasion defenses both contribute to nonhost resistance in Arabidopsis. Science 310:1180-1183.

McDowell, J. M., and Dangl, J. L. 2000. Signal transduction in the plant immune response. Trends Biochem. Sci. 25:79-82.

Niggeweg, R., Thurow, C., Weigel, R., Pfitzner, U., and Gatz, C. 2000. Tobacco TGA factors differ with respect to interaction with NPR1, activation potential and DNA-binding properties. Plant Mol. Biol. 42:775-788.

Nishimura, M. T., Stein, M., Hou, B. H., Vogel, J. P., Edwards, H., and Somerville, S. C. 2003. Loss of a callose synthase results in salicylic acid-dependent disease resistance. Science 301:969-972.

Overmyer, K., Brosche, M., and Kangasjarvi, J. 2003. Reactive oxygen species and hormonal control of cell death. Trends Plant Sci. 8:335-342.

Shah, J. 2003. The salicylic acid loop in plant defense. Curr. Opin. Plant Biol. 6:365-371.

Shah, J., Tsui, F., and Klessig, D. F. 1997. Characterization of a salicylic acid-insensitive mutant (sail) of Arabidopsis thaliana, identified in a selective screen utilizing the SA-inducible expression of the tms 2 gene. Mol. Plant-Microbe Interact. 10:69-78.

Thaler, J. S., Owen, B., and Higgins, V. J. 2004. The role of the jasmonate response in plant susceptibility to diverse pathogens with a range of lifestyles. Plant Physiol. 135:530-538.

Thomma, B., Eggermont, K., Penninckx, I., Mauch-Mani, B., Vogelsang, R., Cammue, B. P. A., and Broekaert, W. F. 1998. Separate jasmonatedependent and salicylate-dependent defense-response pathways in Arabidopsis are essential for resistance to distinct microbial pathogens. Proc. Natl. Acad. Sci. U.S.A. 95:15107-15111.
Uknes, S., Mauch-Mani, B., Moyer, M., Potter, S., Williams, S., Dincher, S., Chandler, D., Slusarenko, A., Ward, E., and Ryals, J. 1992. Acquired resistance in Arabidopsis. Plant Cell 4:645-656.

van Wees, S. C., and Glazebrook, J. 2003. Loss of non-host resistance of Arabidopsis NahG to Pseudomonas syringae pv. phaseolicola is due to degradation products of salicylic acid. Plant J. 33:733-742.

Vleeshouwers, V. G., van Dooijeweert, W., Govers, F., Kamoun, S., and Colon, L. T. 2000. The hypersensitive response is associated with host and nonhost resistance to Phytophthora infestans. Planta 210:853-864.

Ward, E. R., Uknes, S. J., Williams, S. C., Dincher, S. S., Wiederhold, D. L., Alexander, D. C., Ahl-Goy, P., Metraux, J. P., and Ryals, J. A. 1991. Coordinate gene activity in response to agents that induce systemic acquired resistance. Plant Cell 3:1085-1094.

Weigel, R. R., Pfitzner, U. M., and Gatz, C. 2005. Interaction of NIMIN1 with NPR1 modulates PR gene expression in Arabidopsis. Plant Cell 17:1279-1291.

Wiermer, M., Feys, B. J., and Parker, J. E. 2005. Plant immunity: The EDS1 regulatory node. Curr. Opin. Plant Biol. 8:383-389.

Wildermuth, M. C., Dewdney, J., Wu, G., and Ausubel, F. M. 2001. Isochorismate synthase is required to synthesize salicylic acid for plant defence. Nature 414:562-565.

Yu, D., Liu, Y., Fan, B., Klessig, D. F., and Chen, Z. 1997. Is the high basal level of salicylic acid important for disease resistance in potato? Plant Physiol. 115:343-349.

Zhang, S., and Klessig, D. 1997. Salicylic acid activates a 48-kD MAP kinase in tobacco. Plant Cell 9:809-824

Zhou, J. M., Trifa, Y., Silva, H., Pontier, D., Lam, E., Shah, J., and Klessig, D. F. 2000. NPR1 differentially interacts with members of the TGA/OBF family of transcription factors that bind an element of the PR-1 gene required for induction by salicylic acid. Mol. Plant-Microbe Interact. 13:191-202.

Zhou, N., Tootle, T. L., Tsui, F., Klessig, D. F., and Glazebrook, J. 1998. PAD4 functions upstream from salicylic acid to control defense responses in Arabidopsis. Plant Cell 10:1021-1030. 